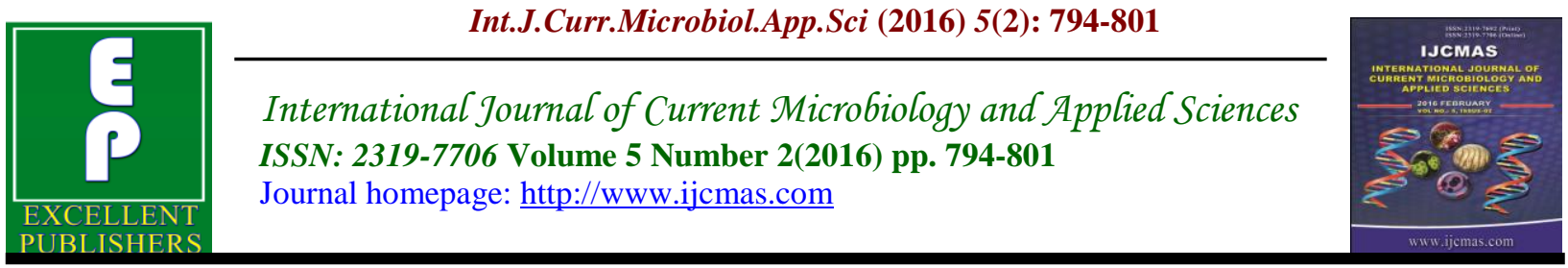

Original Research Article

doi: http://dx.doi.org/10.20546/ijcmas.2016.502.090

\title{
Impact of Post-Emergence Application of Dichlorophenoxy Acetic Acid (2,4-D) Herbicide on Growth and Development of Three Weeds Associated with Maize Growth
}

\author{
Hanan. M. Abou El-Ghit* \\ Botany and Microbiology department, Science Faculty, Helwan University, Cairo, Egypt \\ *Corresponding author
}

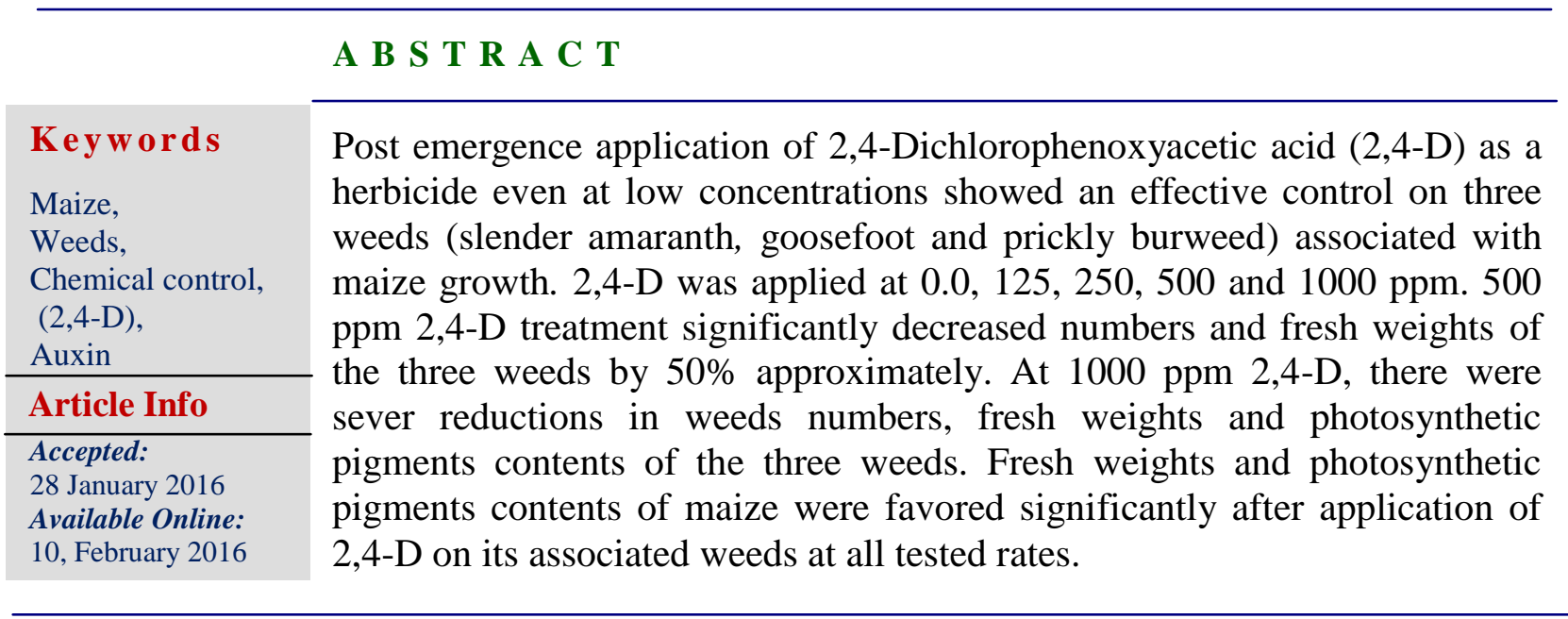

\section{Introduction}

Maize (Zea mays L.) is the second most important cereal crop in Egypt in terms of total food production. It is grown for fodder as well as for grain. The grains of maize are used in a variety of ways by the human beings. Weeds are a major problem in crop production and drastically decrease crop yield. Weed control is an important management practice to ensure optimum grain yield. Yield losses due to weeds have been reported up to $35 \%$ (Oerke, 2005; Dangwal, et al. 2010). The use of herbicides may reduce such losses, as herbicides may reduce the weed infestation provided that the herbicide-treated weeds are not herbicide resistant.
Weed compete with crop plants for soil nutrients, light and water. Slender amaranth (Amaranthus viridis), goosefoot (Chenopodium album) and prickly burweed (Xanthium spinosum) are troublesome broad leaved weeds associate with maize growth (Malik et al. 2006). Amaranthus viridis is a cosmopolitan weed belong to family Amaranthaceae, Chenopodium album is a fast-growing weed belong to Chenopodiaceae, whereas Xanthium spinosum is a noxious weed in Asteraceae family.

Some herbicides are synthetic mimics of natural plant hormones (Kellogg et al., 
2000). Selective herbicides kill specific targets, while leaving the desired crop relatively unharmed. Herbicide use has undoubtedly contributed to crop yield increases and the efficiency of production (Andrew, 2012). Some substantial benefits can be gained through the use of herbicides to manage unwanted vegetation. Unintended but economically important damage to crop plants is sometimes a consequence of the inappropriate use of herbicides (Robert, 1941 and Mehmeti, 2004). Herbicides have different modes of actions on enzymes (catalysts of biological reactions), this means that the target enzymes may no longer function properly, or at all. Herbicide distort enzymes molecules in some way, so component chemicals for the reaction accumulate and may be directly or indirectly damaging. Absence of the reaction's products will restrict growth, either through starvation of key building blocks or because the reaction makes chemicals which normally protect the plant (Santra and Baumann, 2008).

Over decades, the so-called auxin herbicides had resisted all efforts to elucidate their molecular interactions and the biochemical and physiological basis of their phytotoxicity (Cobb, 1992).

Auxin herbicides started a new era of weed control in modern crop production due to their systemic mobility in the plant and to their selective action, preferentially against dicot weeds in cereal crops (Cobb, 1992 and Grossmann, 2007). Auxin herbicides mimic the action of the main auxin, indole-3-acetic acid (IAA) in higher plants (Cobb, 1992). However, they are long-lasting, particularly due to their higher stability in the plant, and, therefore, more effective than IAA. Auxins stimulate a variety of growth and developmental processes when present at low concentrations at the cellular sites of action. However, with increasing concentration and auxin activity in the tissue, growth is disturbed and the plant is lethally damaged (Grossmann, 2003).

In general, grasses are much less sensitive to synthetic auxin herbicides than are dicots. So, for example, at the doses used to kill dandelions, grasses are largely unaffected (Cobb, 1992 and Grossmann 2003). Auxinbased herbicides are referred to as "selective" herbicides because they kill socalled "broadleaf" plants (dicots) but not grasses, hence, that's why they're popular herbicides with growers of lawns.

Phenoxy herbicides work by binding to some or all of the same sites in the plant cells as naturally occurring IAA. While naturally occurring IAA concentrations in the cell are highly regulated, when phenoxy herbicides are applied, plant growth becomes deregulated. This deregulation causes twisting, thickening and elongation of leaves and stems and eventually leads to plant death as the plant cannot mobilize reserves, repair or function properly (Song, 2014).

2,4-D was the first compound that, at low doses, could selectively control dicots broadleaf plants, but not most monocots narrow leaf crops like wheat, maize (corn), rice, and similar cereal grass crops (Andrew et al., 2010). 2,4-D generally has low toxicity for humans (Aylward, 2010).

\section{Materials and Methods}

A pot experiment was carried out to examine the effect of foliar application of 2,4-Dichlorophenoxyacetic acid (2,4-D) as a herbicide on the growth of three weeds (slender amaranth, goosefoot and prickly burweed) which grow associated with maize plant. 2,4-D was applied at different 
concentrations $(0.0,125,250,500$ and 1000 ppm). Seeds of Zea mays var. amylacea and the three weeds were obtained from the Agriculture Research Center, Ministry of Agriculture, Giza, Egypt. Maize and weeds were grown in pots $(40 \mathrm{~cm}$ in diameter) of $15 \mathrm{~kg}$ of clay loamy soil.

Fifteen seeds of each weed were sown with ten seeds of maize. 2,4-D was sprayed on weeds with a hand sprayer after 2 weeks of sowing and repeated after one week. Precautions were taken to avoid damage of maize plant. There were three replicates of each treatment of 2,4-D. Irrigation was done regularly to maintain soil field capacity. The effect of 2,4-D herbicide was measured after five weeks of sowing by counting of slender amaranth, goosefoot and prickly burweed numbers (plants/pot) and estimation of fresh weights of each weed (g/ 3plants). Also, fresh weight (g) of maize plant was estimated after 2,4-D application on the associated weeds. Chlorophyll a, b and carotenoids contents in the fresh leaves of weeds and maize (mg/g. F.W) were determined in samples according to Metzener et al., (1965). Data were statistically analyzed by Snedecore and Cochran (1981) method.

\section{Results and Discussion}

Tables (1 and 2) indicate that 2,4-D herbicide controlled both number and fresh weights of slender amaranth, goosefoot and prickly burweed plants even at low rates. 500 ppm 2,4-D treatment led to approximately $50 \%$ reduction in plant numbers and plants fresh weights. Few plants of the slender amaranth, goosefoot and prickly burweed plants survived at $1000 \mathrm{ppm}$ 2,4-D, but they were very small and damaged. Concerning the photosynthetic pigments content of weeds, it was found that chlorophyll a, b and carotenoids of 2,4 D sprayed weeds were considerably diminished compared with their corresponding controls and this effect was in a concomitant trend with that of growth parameters in response to 2,4-D treatments (Tables 3,4,5). The lowest pigments content was recorded by the highest 2,4-D concentration (1000 ppm).

The reducing effect of 2,4-D on slender amaranth, goosefoot and prickly burweed plants may be a consequence effect of increasing the endogenous auxin concentrations to supraoptimal and extensive perception by auxin receptors (Badescu, 2006 and Dharmasiri et al. 2005). Also, it may be attributed to stimulation of ethylene production which trigger the overproduction of abscisic acid (ABA), causing its accumulation. Over production of ethylene causes number of plant responses, including epinasty and senescence.

Accumulated ABA in the shoot tissue is translocated within the plant and mediates events in the auxin herbicide syndrome, such as growth inhibition, tissue decay and plant death. The recent identification of receptors for auxin perception and the discovery of a new hormone interaction in signalling between auxin, ethylene and the upregulation of abscisic acid biosynthesis account for a large part of the repertoire of auxin-herbicide-mediated responses, which include growth inhibition, senescence and tissue decay in sensitive dicots (Chae et al. 2005).

Stimulation of ethylene biosynthesis plays a key role in eliciting the herbicidal symptoms in sensitive plants (Grossmann, 2010). These results are in agreement with Hansen and Grossmann (2000), Grossmann (2003) and Kepinski et al. (2005). Chae (2005) reported that ethylene is a factor in defoliation caused by 2,4-D. Because plants can't break down 2,4-D, it's action persists. 
Table.1 Effect of 2,4-D Application on Numbers of Slender Amaranth, Goosefoot and Prickly Burweed

\begin{tabular}{|c|c|c|c|}
\hline \multirow{2}{*}{$\begin{array}{c}\text { 2,4-D conc. } \\
(\mathbf{p p m})\end{array}$} & \multicolumn{3}{|c|}{ Plant numbers/pot } \\
\cline { 2 - 4 } & $\begin{array}{c}\text { Slender } \\
\text { amaranth }\end{array}$ & Goosefoot & $\begin{array}{c}\text { Prickly } \\
\text { burweed }\end{array}$ \\
\hline $\mathbf{0 . 0}$ & 15 & 15 & 15 \\
\hline $\mathbf{1 2 5}$ & 13.6 & 12.3 & 13.3 \\
\hline $\mathbf{2 5 0}$ & 11.3 & 9.6 & 10.6 \\
\hline $\mathbf{5 0 0}$ & 9.3 & 7.3 & 9.3 \\
\hline $\mathbf{1 0 0 0}$ & 3.3 & 4.6 & 5.3 \\
\hline L.S.D. at 5\% & 0.51 & 0.92 & 0.82 \\
\hline L.S.D at $\mathbf{1 \%}$ & 1.30 & 1.83 & 1.73 \\
\hline
\end{tabular}

Table.2 Effect of 2,4-D Application on Fresh Weights of Slender Amaranth, Goosefoot and Prickly Burweed

\begin{tabular}{|c|c|c|c|}
\hline \multirow{2}{*}{$\begin{array}{c}\text { 2,4-D conc. } \\
\text { (ppm) }\end{array}$} & \multicolumn{3}{|c|}{ Fresh weights (g/ 3 plants) } \\
\cline { 2 - 4 } & $\begin{array}{c}\text { Slender } \\
\text { amaranth }\end{array}$ & Goosefoot & $\begin{array}{c}\text { Prickly } \\
\text { burweed }\end{array}$ \\
\hline $\mathbf{0 . 0}$ & 5.56 & 6.01 & 5.09 \\
\hline $\mathbf{1 2 5}$ & 3.78 & 5.13 & 3.42 \\
\hline $\mathbf{2 5 0}$ & 2.23 & 3.88 & 2.33 \\
\hline $\mathbf{5 0 0}$ & 1.78 & 2.03 & 1.58 \\
\hline $\mathbf{1 0 0 0}$ & 0.84 & 0.91 & 0.77 \\
\hline L.S.D. at 5\% & 0.063 & 0.067 & 0.059 \\
\hline L.S.D at 1\% & 0.081 & 0.091 & 0.078 \\
\hline
\end{tabular}

Table.3 Effect of 2,4-d Treatments on Chlorophyll "a" Content (mg/g. Fresh weight) in Leaves of Slender Amaranth, Goosefoot and Prickly Burweed

\begin{tabular}{|c|c|c|c|}
\hline $\begin{array}{c}\text { 2,4-D conc. } \\
(\mathbf{p p m})\end{array}$ & \multicolumn{3}{|c|}{ Chl. a (mg/g. f.wt) } \\
\cline { 2 - 4 } & $\begin{array}{c}\text { Slender } \\
\text { amaranth }\end{array}$ & Goosefoot & $\begin{array}{c}\text { Prickly } \\
\text { burweed }\end{array}$ \\
\hline $\mathbf{0 . 0}$ & 3.753 & 3.971 & 2.953 \\
\hline $\mathbf{1 2 5}$ & 3.013 & 3.123 & 2.222 \\
\hline $\mathbf{2 5 0}$ & 2.345 & 2.133 & 1.791 \\
\hline $\mathbf{5 0 0}$ & 1.326 & 1.544 & 0.987 \\
\hline $\mathbf{1 0 0 0}$ & 0.439 & 0.533 & 0.418 \\
\hline L.S.D. at 5\% & 0.035 & 0.052 & 0.035 \\
\hline L.S.D at 1\% & 0.057 & 0.083 & 0.046 \\
\hline
\end{tabular}


Table.4 Effect of 2,4-D Treatments on Chlorophyll "B" Content (Mg/G Fresh Weight) in Leaves of Slender Amaranth, Goosefoot and Prickly Burweed

\begin{tabular}{|c|c|c|c|}
\hline \multirow{2}{*}{$\begin{array}{c}\text { 2,4-D } \\
(\mathbf{p p m})\end{array}$} & \multicolumn{3}{|c|}{ Chl. b (mg/g. f.wt) } \\
\cline { 2 - 4 } & $\begin{array}{c}\text { Slender } \\
\text { amaranth }\end{array}$ & Goosefoot & $\begin{array}{c}\text { Prickly } \\
\text { burweed }\end{array}$ \\
\hline $\mathbf{0 . 0}$ & 2.53 & 2.83 & 2.31 \\
\hline $\mathbf{1 2 5}$ & 1.66 & 2.06 & 1.62 \\
\hline $\mathbf{2 5 0}$ & 1.01 & 1.33 & 1.01 \\
\hline $\mathbf{5 0 0}$ & 0.71 & 0.51 & 0.81 \\
\hline $\mathbf{1 0 0 0}$ & 0.029 & 0.027 & 0.033 \\
\hline L.S.D. at 5\% & 0.033 & 0.017 & 0.055 \\
\hline L.S.D at 1\% & 0.047 & 0.029 & 0.071 \\
\hline
\end{tabular}

Table.5 Effect of 2,4-D Treatments on Carotenoids Content ( $\mathrm{Mg} / \mathrm{G}$ Fresh Weight) in Leaves of Slender Amaranth, Goosefoot and Prickly Burweed

\begin{tabular}{|c|c|c|c|}
\hline \multirow{2}{*}{$\begin{array}{c}\mathbf{2 , 4 - D} \\
(\mathbf{p p m})\end{array}$} & \multicolumn{3}{|c|}{ Carotenoids (mg/g.f.wt) } \\
\cline { 2 - 4 } & $\begin{array}{c}\text { Slender } \\
\text { amaranth }\end{array}$ & Goosefoot & $\begin{array}{c}\text { Prickly } \\
\text { burweed }\end{array}$ \\
\hline $\mathbf{0 . 0}$ & 1.75 & 1.49 & 1.56 \\
\hline $\mathbf{1 2 5}$ & 1.05 & 1.07 & 1.09 \\
\hline $\mathbf{2 5 0}$ & 0.96 & 0.90 & 0.72 \\
\hline $\mathbf{5 0 0}$ & 0.71 & 0.57 & 0.44 \\
\hline $\mathbf{1 0 0 0}$ & 0.36 & 0.31 & 0.27 \\
\hline L.S.D. at 5\% & 0.021 & 0.019 & 0.051 \\
\hline L.S.D at 1\% & 0.041 & 0.028 & 0.073 \\
\hline
\end{tabular}

Fig.1 A Maize Fresh Weight (g) and (B) Chlorophyll a, b and Carotenoids Contents (mg/g.f.wt) of Maize Leaves after 2,4-d Application on its Associated Weeds. L.S.D at 5\% for F.wt, Chl a, Chl b and Carotenoids: 0.46, 0.0.065, 0.044, 0.035

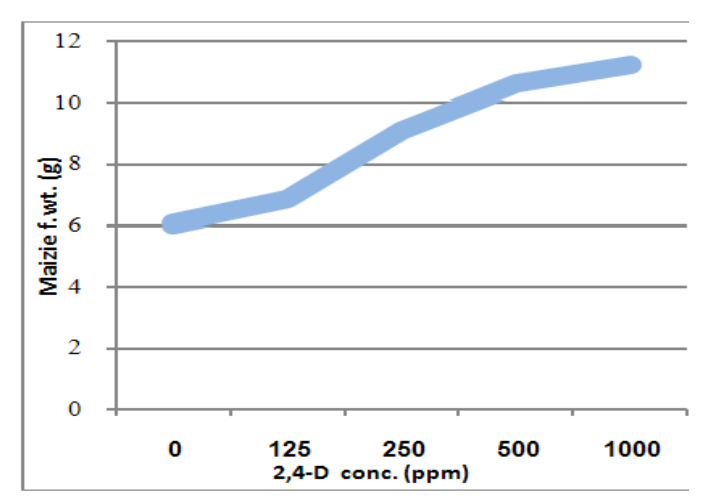

(A)

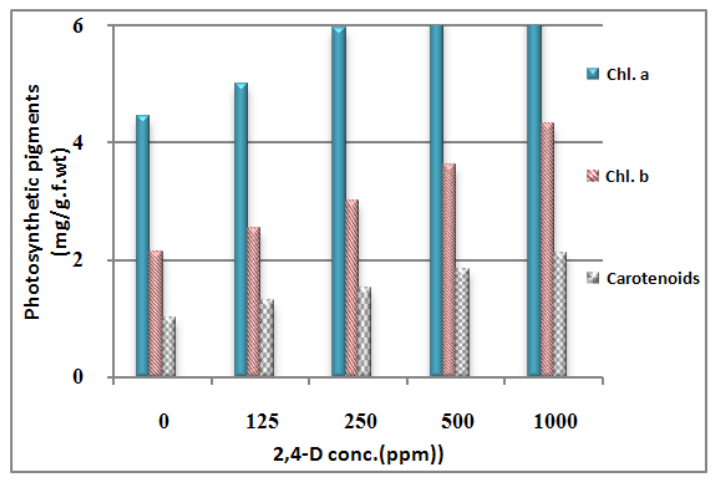

(B) 
Auxin herbicides and IAA are directly able to trigger activation of NCED (9-cisepoxycarotenoid dioxygenase) gene, which in turn participate in ABA biosynthesis and accumulation (Hamner and Tukey 1944). In addition, NCED gene expression and activity appears to be stimulated by auxininduced ethylene, leading to lasting ABA biosynthesis (Sterling and Hall, 1997) and Kraft et al. (2007). Taylor et al. (2005) reported that, ABA biosynthesis is induced in the shoot tissue of Arabidopsis by increasing xanthophyll cleavage, leading to increased production of the ABA precursor, xanthoxin. Xanthoxin production which is a key regulated step in the ABA pathway is catalyzed by the plastid enzyme NCED (9cis-epoxycarotenoid dioxygenase), which is encoded by a family of NCED genes. NCED genes were assumed to be regulated by auxin treatment. Auxin treatment enhanced NCED precursor supply, hence, contribute consequently to ABA accumulation (Symonds et al., 2005; Raghavan et al., 2006). Walsh et al. (2006) and Grossmann, (2007) reported that, 2,4-D treated Arabidopsis showed that, expression of NCED genes are involved in biosynthesis and accumulation of abscisic acid.

Data presented in Fig. 1 A \& B indicate that maize fresh weight $(\mathrm{g})$ and photosynthetic pigments content (mg/g.f.wt) were favored significantly after application of 2,4-D on its associated weeds at all tested rates. The increasing of maize fresh weight and photosynthetic pigments content of maize leaves after 2,4-D application on its associated weeds may be attributed to the controlling of weed growth and decreasing competition between maize and its associated weeds on soil nutrients, water and light. Also the undamaging of maize may be attributed to its resistance. This agrees with Abdullah et al. (2007), Khan and Haq
(2004), Bogdan (2007) and Dangwal, et al. (2010) who recorded a strong enhancement of photosynthetic pigments content (mg/g.f.wt) of maize crop after 2,4-D application on its associated weeds. Grasses are more resistant to such herbicides because of differences in leaf morphology, translocation of the herbicide inside the plant, and the ability to metabolize (breakdown) synthetic auxins (Mehmeti and Demaj, 2010).

\section{References}

Abdullah, G., I, Hassan., A, Khan and M, Munir. 2007. Effect of planting methods and herbicides on yield and yield components of maize. Pak J. Weed Sci. Res. 13 (1-2): 39-48.

Andrew, H., , H, Cobb., P, John., and, H, Reade. 2010. Herbicides and Plant Physiology. Wiley-Blackwell; 2nd edition, ISBN 978-1405129350.

Andrew, P. 2012. "Dow Weed Killer, Nearing Approval, Runs Into Opposition". The New York Times. Retrieved April 25, 2012.

Aylward, F. 2010. Biomonitoring data for 2,4-dichlorophenoxyacetic acid in the United States and Canada: interpretation in a public health risk assessment context using Biomonitoring Equivalents. Environ Health Perspect. Feb;118(2):177-81.

Badescu, GO. and RM, Napier.2006. Receptors for auxin. Trends Plant Sci.;11:217-223.

Bogdan, I., S, Vaju. and P, Morar. 2007. Research concerning weed control in maize crop. Cercetari Agronomice in Moldova. 1 (129): 16-21.

Chae, HS., JJ, Kieber. and E, Etobrute. 2005. Role of ACS turnover in regulating ethylene biosynthesis. Trends Plant Sci.;10:291-296.

Cobb, A. (1992). Herbicides and Plant 
Physiology. Chapman Hall; Auxintype herbicides; pp. 82-106.

Dangwal, R. L., T, Singh., T, Singh., and C, Sharma. 2010. Effect of weeds on the yield of wheat crop in Tehsil Nowshera. Journal of American Science. 6 (10): 405-407.

Dharmasiri, N., S, Dharmasiri., M, Estelle. 2005. The F-box protein TIR1 is an auxin receptor. Nature.;435:441445.

Donna, F. (2014). "Enlist weed control system in Canada. A new tool for managing hard to control and resistant weeds". AG Annex. Retrieved May 3, 2014.

Fedtke, C and SO, Duke. 2005. Herbicides. In: B. Hock, E.F. Elstner. Plant toxicology,. Marcel Dekker, New York, 648.

Grossmann, k . 2010. Auxin herbicides: current status of mechanism and mode of action. Herbologia. Feb; 66(2):113-200.

Grossmann, K. 2000. Mode of action of auxin herbicides: a new ending to a long, drawn out story. Trends Plant Sci: 5: 506-509.

Grossmann, K. 2003. Mediation of herbicide effects by hormone interactions. J Plant Growth Regul.;22:109-122.

Grossmann, K. 2007. "Auxin Herbicide Action: Lifting the Veil Step by Step", Plant Signalling \& Behavior 2:421-423.

Hansen, H and K, Grossmann. 2000. Auxininduced ethylene triggers abscisic acid biosynthesis and growth inhibition. Plant Physiol. 124:14371448.

Kellogg, RL., R, Nehring, A, Grube., DW, Goss, and S, Plotkin. 2000. "Environmental indicators of pesticide leaching and runoff from farm fields". United States Department of Agriculture Natural
Resources Conservation Service. Retrieved 2010-08-26.

Kepinski, S. and Leyser, O. (2005). The Arabidopsis TIR1 protein is an auxin receptor. Nature.;435:446-451.

Khan, M. and N, Haq. 2004. Weed control in maize (Zea mays L.) with pre and post emergence herbicides. Pak. J. Weed Sci. Res. 10 (12): 39-46.

Kraft, M., R, Kuglitsch., J, Kwiatkowski., M, Frank., K, Grossman. 2007. Indole-3-acetic acid and auxin herbicides upregulate 9-cisepoxycarotenoid dioxygenase gene expression and abscisic acid accumulation in cleavers (Galium aparine): Interaction with ethylene. $\mathrm{J}$ Exp Bot.;58:1497-1503.

Malik, M. A., F, Zahoor., S. H, Abbas and, M, Ansar. 2006. Comparative study of different herbicides for control of weeds in rainfed maize (Zea mays L.). WSSP Absts. Weed Sci. Soc. Pak., 62p.

Mehmeti, A. 2004. Three-year average effects of herbicides on weeds in potato and the yield of the crop. Herbologia 5 (1): 85-94.

Mehmeti, A. and A, Demaj. 2010. Efficiency of post-emergence herbicides on weeds in wheat and the yield of the crop. Jubilee Scientific Conference, Scientific works. Agriculture University, Plovdiv, Bulgaria LV (2):119-125.

Metzener, H., H, Rau., and H, Senger. 1965. Unter suchungen zur synchronisier barteit einzelner pigmentan angel mutanten von chlorell. Planta. 65:186.

Oerke, E. C. (2005). Crop losses to pests. J. Agric. Sci.144: 31-43.

Ognjanović, R. 1984. Struktura korovskih zajednica u uslovima dvopolja pšenica-kukuruz. Drugi Kongres o korovima, Osijek. 145-152. 
Powles, SB and C, Preston 2006. Evolved glyphosate resistance in plants: biochemical and genetic basis of resistance. Weed Technology, 20 (6):282-289.

Raghavan, C., EK, Ong., MJ, Dalling., TW, Stevenson. 2006. Regulation of genes associated with auxin, ethylene and ABA pathways by $2,4-$ dichlorophenoxy-acetic acid in Arabidopsis. Funct Integ Genom.;6:60-70.

Robert, P. 1941. New Compounds. Some Chlorophenoxyacetic Acids J. Am. Chem. Soc., 63(6): 1768-1769.

Santra, S and U, Baumann. 2008. Experience of nitisinone for the pharmacological treatment of hereditary tyrosinaemia type 1. Expert Opinion on Pharmacotherapy, 9, (7): 1229-1236.

Snedecore, G.W. and Cochran, W.G, 1981. "Statistical Methods". 7th ed., Iowa State Univ. Press, Ames, Iowa,USA, $305 \mathrm{P}$.

Song, Y, 2014. Insight into the mode of action of 2,4-dichlorophenoxyacetic acid (2,4-D) as an herbicide. J Integr Plant Biol. Feb;56(2):106-131.

Sterling, TM and , JC, Hall. 1997. Mechanism of action of natural auxins and the auxinic herbicides. Herbicide Activity: Toxicology, Biochemistry and Molecular Biology. Amsterdam: IOS Press;. pp. 111-141.
Symonds, RC., T, Sonneveld., A, Burbidge., P, Stevenson and , IB, Taylor. 2005. Regulation and manipulation of the biosynthesis of abscisic acid including the supply of xanthophylls precursors. J Plant Growth Regul.;24:253-273.

Taylor, IB., BJ, Mulholland., AC., Jackson., JM, McKee., HW, Hilton., C, Raghavan., EK, Ong., MJ, Dalling., and TW, Stevenson. 2006. Regulation of genes associated with auxin, ethylene and ABA pathways by 2,4-dichlorophenoxy-acetic acid in Arabidopsis. Funct Integ Genom.;6:60-70.

Walsh, TA., R, Neal., AO, Merlo., M, Honma., GR, Hicks., K, Wolff., W Matsumura., and JP, Davies, 2006. Mutations in an auxin receptor homolog AFB5 and in SGT1b confer resistance to synthetic picolinate auxins and not to 2,4dichlorophenoxyacetic acid or indole-3-acetic acid in Arabidopsis. Plant Physiol.;142:542-552.

Wong, P.K and L, Chang, 1988. The effects of 2,4-D herbicide and organophosphorus insecticides on growth, photosynthesis, and chlorophyll $a, \quad b \quad$ synthesis of Chlamydomonas reinhardti. Environmental Pollution. 55(3):17989.

\section{How to cite this article:}

Hanan. M. Abou El-Ghit. 2016. Impact of Post-Emergence Application of Dichlorophenoxy Acetic Acid (2,4-D) Herbicide on Growth and Development of Three Weeds Associated with Maize Growth. Int.J.Curr.Microbiol.App.Sci. 5(2): 794-801. doi: http://dx.doi.org/10.20546/ijcmas.2016.502.090 